\title{
Serum lysozyme activity in coeliac disease: a possible aid to the diagnosis of malignant change
}

\author{
BT COOPER, SO UKABAM, RE BARRY, AE READ \\ From the University Department of Medicine, Bristol Roval Infirmary, Bristol BS2 $8 \mathrm{HW}$
}

SUMMARY Serum lysozyme activities were measured in 34 control subjects, 13 untreated adult coeliac patients, 21 adult coeliac patients on a gluten-free diet, and eight coeliac patients with a histiocytic lymphoma.

Serum lysozyme activities were raised in three untreated patients, three patients treated with a gluten-free diet, and in only two patients with coeliac disease and lymphoma. Serum lysozyme estimations cannot be recommended as an aid to the diagnosis of lymphoma in patients with coeliac disease.

Malignant lymphoma is the most serious complication of coeliac disease but its diagnosis is frequently delayed, because the symptoms and signs are similar to those of the underlying coeliac disease, and survival is usually very poor. ${ }^{1-5}$ Earlier diagnosis and treatment might allow better prospects of survival but there are, as yet, no specific diagnostic features. However, Hodges et $a l^{6}$ found that five of eight patients with malabsorption, a flat jejunal biopsy, and malignant lymphoma had raised lysozyme activities. In contrast none of a group of uncomplicated coeliac patients, seven untreated and eight treated with a gluten-free diet, had serum lysozyme activities above the normal range. They concluded that estimation of serum lysozyme activity might be of value in the diagnosis of lymphoma complicating coeliac disease. The aim of the present study is to see if these findings are reproducible.

\section{Material and methods}

MEASUREMENT OF SERUM LYSOZYME

Serum lysozyme activity was measured using a modification of the turbidometric assay of Smolelis and Hartsell ${ }^{7}$ which had previously been described. ${ }^{6}$ Egg white lysozyme (Sigma) was used as standard. Samples were coded so that the assay was done in ignorance of the patient group to which the serum belonged.

PATIENTS AND CONTROLS

Serum was obtained from 34 adult control subjects

Accepted for publication 22 May 1981
(19 men: 15 women) who had no inflammatory or intestinal disease. Serum was also obtained or made available from 13 untreated adult coeliacs $(6 \mathrm{men}$ : 7 women) who had been diagnosed by jejunal biopsy, 21 adult coeliacs (6 men: 15 women) who had responded to a gluten-free diet, and eight adult coeliacs ( 5 men: 3 women) with a complicating lymphoma. All the lymphoma patients had a flat jejunal biopsy and seven showed response to a gluten-? free diet. The remaining patient was Irish and presented with a lymphoma but gave a history of severe undiagnosed diarrhoea and anaemia in childhood. The lymphoma in each case was classified histologically as a histiocytic lymphoma.

\section{STORAGE}

All sera were stored at $-20^{\circ} \mathrm{C}$. Sera from all the lymphoma patients, and nine of the untreated coeliacs, was obtained from a serum bank where they had been stored for six months to eight years. The sera had not been thawed in the period between the initial freezing and the thawing for the lysozyme assay.

\section{STATISTICS}

All groups were compared using the Kruskal-Wallis one way analysis of variance by ranks. Correlations were studied with Spearman's rank correlation coefficient.

\section{Results}

The serum lysozyme activities of the control subjects and the various groups of coeliac patients are shown in the Figure. The mean activity of the controls was 


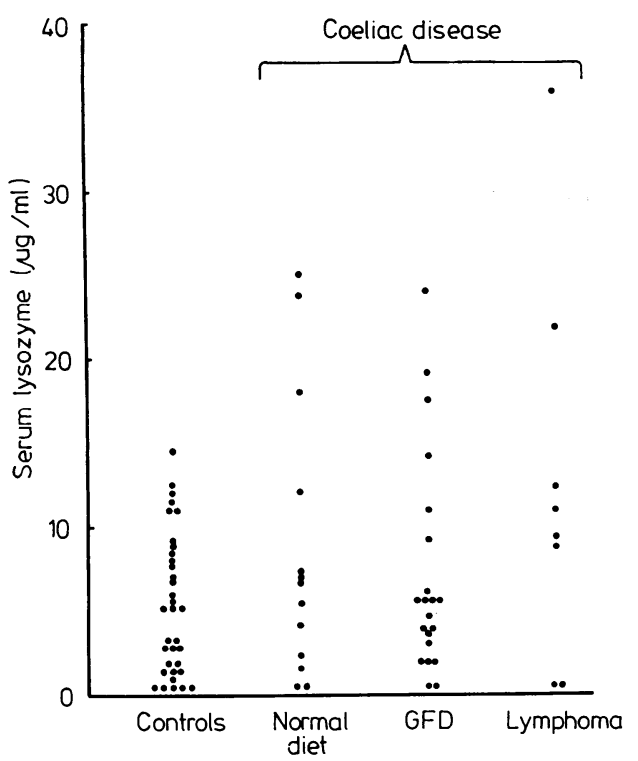

Serum lysozyme activities in control subjects and in three groups of coeliac patients $(G F D=$ gluten-free diet $)$

$5.8 \pm 0.7$ (SEM) $\mu \mathrm{g} / \mathrm{ml}$, of untreated coeliacs was $8.7 \pm 2.3 \mu \mathrm{g} / \mathrm{ml}$, of coeliacs responding to a glutenfree diet was $7 \cdot 1 \pm 1.4 \mu \mathrm{g} / \mathrm{ml}$, and of coeliacs with lymphoma was $12.5 \pm 4 \cdot 1 \mu \mathrm{g} / \mathrm{ml}$. There was no difference between the groups $(\mathrm{H}=0.7 ; \mathrm{p}>0.8)$. Three untreated and three treated coeliacs had serum lysozyme activities outside the range of the normal controls. Only two lymphoma patients had activities greater than the upper limit of the normal controls. There was no correlation between the age of sera and the serum lysozyme activities for the untreated coeliacs and the lymphoma patients $\left(\Sigma \mathrm{D}^{2}=1299\right.$; $\mathrm{n}=21$ ), moreover the two most recently diagnosed lymphoma patients had the lowest serum lysozyme activities.

\section{Discussion}

The lymphoma patients in the paper of Hodges et $a l^{6}$ were thought to have malignant histiocytosis of the intestine. Therefore, as macrophages produce lysozyme, ${ }^{8}$ it was logical to think that these patients might have raised serum lysozyme activity. However, there is controversy over the nature of these histiocytic tumours complicating coeliac disease. Moreover the diagnosis of malignant histiocytosis is difficult in retrospect on stored material and all our cases were classified as histiocytic lymphomas. It was not felt possible to classify them as cases of malignant histiocytosis. We think that whatever the histopathological arguments, it is likely that the histiocytic tumours complicating our coeliac patients are the same as the histiocytic tumours complicating the cases of Hodges et $a^{6}{ }^{6}$. Therefore our conclusions are based on results obtained from a similar group of patients.

Our study has shown that serum lysozyme activity is not raised in the majority of coeliac patients with lymphoma and that untreated and treated coeliacs may have raised serum activities. The findings suggest that serum lysozyme is of little value in diagnosing lymphoma in coeliac patients. A previous study has shown that the ESR was raised in $71 \%$ of 21 coeliac patients at presentation of their lymphoma. ${ }^{5}$ Therefore, a raised ESR is likely to be of more value in arousing suspicion of a developing lymphoma in a coeliac patient.

The sera from 20 of the patients were obtained from a serum bank where they had been stored for six months to eight years. There is evidence that serum activity deteriorates with storage ${ }^{69}$ However, in our study there was no evidence that the older sera had the lower activities and indeed the two most recently diagnosed lymphoma patients had the lowest serum activities.

It may be suggested that those patients with raised serum activity could have been developing lymphoma. This is unlikely because the three untreated patients with raised activities have been followed for six months to four years after the sera were taken with no evidence of lymphomatous change. Their serum lysozyme activities have returned to normal. The three treated patients have been followed for six months and their serum activities have returned to normal.

As some patients with coeliac disease have increased numbers of jejunal mucosal histiocytes ${ }^{10}$ it is perhaps not surprising that some uncomplicated coeliacs have raised serum lysozyme activities and that this is not a specific finding in coeliac patients with lymphoma. Moreover, Mallas et al ${ }^{11}$ found that the mean serum lysozyme activity in a group of 31 coeliacs was significantly higher that the mean activity of a control group. However Hodges et al ${ }^{6}$ and ourselves found normal mean activities in treated and untreated coeliac patients.

In conclusion, raised serum lysozyme activity is not seen in all coeliac lymphoma patients and may be seen in uncomplicated coeliac patients. Therefore, we cannot recommend routine measurement of serum lysozyme activities as a screening or diagnostic test for lymphoma in coeliac patients.

We would like to thank Dr RN Allan of the Gastroenterology Unit, General Hospital, Birmingham for 
donation of sera from lymphoma patients and $\mathrm{Dr}$ $\mathrm{H}$ Thompson of the Pathology Department, General Hospital, Birmingham for his helpful comments on the histology of the lymphomas.

\section{References}

${ }^{1}$ Gough KR, Read AE, Naish JM. Intestinal reticulosis as a complication of idiopathic steatorrhoea. Gut 1962; 3:232-9.

${ }^{2}$ Austad WI, Cornes JS, Gough KR, McCarthy CF, Read AE. Steatorrhoea and malignant lymphoma-the relationship of malignant tumours of lymphoid tissue and coeliac disease. Am J Dig Dis 1967;12:475-90.

${ }^{3}$ Harris OD, Cooke WT, Thompson H, Waterhouse JAH. Malignancy in adult coeliac disease and idiopathic steatorrhoea. Am J Med 1967;42:899-912.

${ }^{4}$ Freeman HJ, Weinstein WM, Shmitka TK, Piercy JRA, Wensel RH. Primary abdominal lymphoma. Presenting manifestations of celiac sprue or complicating dermatitis herpetiformis. Am J Med 1977;63:585-94.

${ }^{5}$ Cooper BT, Holmes GKT, Ferguson R, Cooke WT.
Coeliac disease and malignancy. Medicine (Baltimore) 1980;59:240-61.

${ }^{6}$ Hodges JR, Isaacson P, Eade OE, Wright R. Serum lysozyme levels in malignant histiocytosis of the intestine. Gut 1979;20:854-7.

' Smolelis AN, Hartsell SE. The determination of serum lysozyme. J Bacteriol 1949;58:731-6.

${ }^{x}$ Gordon S, Todd J, Cohn ZA. In vitro synthesis and secretion of lysozyme by mononuclear macrophabes. $J$ Exp Med 1976;139:1228-48.

" Ward M, Mitchell WD, Eastwood M. Complex nature of lysozyme activity: evidence of thermolability in inflammatory bowel disease. J Clin Pathol 1978;31:39-43.

${ }^{10}$ Shiner M. Coeliac disease: Electron microscopy of jejunal mucosa. Clin Gastroenterol 1973;3:33-53.

1 Mallas E, Terry JM, Asquith P, Cooke WT. Serum lysozyme in inflammatory bowel disease and coeliac discase. J Clin Pathol 1976;29:598-600.

Requests for reprints to: Dr BT Cooper, University Department of Medicine, Bristol Royal Infirmary, Bristol BS2 8HW, England. 